УдК 616.314-089+616.314.18-002.4+616.71-018.44

DOI 10.11603/2311-9624.2017.4.8057

(С). А. Огієнко, В. П. Пюрик, О. Г. Попадинець

Івано-Франківський національний медичний університет

\title{
Ультраструктурний стан пародонта при удосконаленні клаптевої операції у лікуванні хворих на генералізований пародонтит
}

Резюме. Серед усіх хірургічних стоматологічних захворювань хвороби пародонта займають одне 3 провідних місць, враховуючи поширеність цієї патології серед населення та ії негативні наслідки (втрата зубів і порушення функцій зубощелепної системи). Тяжкість ГП, часті рецидиви й ускладнення призводять до зниження якості життя пацієнтів, значних соціально-економічних збитків, порушення функції жування та мовлення.

Мета дослідження - підвищення ефективності хірургічного лікування хворих на ГП ІІІ ступеня тяжкості шляхом удосконалення окремих технологічних ланок операцій Цешинського-Відмана-Неймана.

Матеріали і методи. Ми прооперували 46 хворих на хронічний генералізований парадонтит (ГП) III ступеня, яких поділили на дві групи: перша (20 осіб) - проводили традиційну модифіковану операцію Цешинського-Відмана-Неймана; хворим другої групи (26 осіб) - модифіковану операцію Цешинського-Відмана-Неймана, удосконалену методикою пенетрації періосту 3 медикаментозною корекцією (із використанням ротових ванночок з мірамістином та аплікацій метилурацилової мазі з мірамістином на тканини пародонта і післяопераційні шви із застосуванням у післяопераційному періоді препарату «Глутаргін» (спершу в ін’єкціях № 5 внутрішньовенно по 5 мл (2 г) на 200 мл 0,9 \% розчину натрію хлориду 2 рази на добу, а потім у таблетках - 4 таблетки по 0,75 мг 3 рази на день протягом місяця).

Результати досліджень та їх обговорення. Після проведеного лікування встановлено, що середній показник проби Шиллера-Писарєва був вищий у хворих першої групи $(2,5 \pm 0,05)$ \% порівняно 3 відповідним показником другої $(0,95 \pm 0,04)$ \%. Після лікування середній показник індексу кровоточивості становив у першій групі $(0,77 \pm 0,04)$ бала та другої - $(0,32 \pm 0,04)$ бала. Ультраструктурний стан пародонта зазнає позитивних трансформацій у більш стислі терміни в пацієнтів другої групи. Отже, застосування періостальної пенетрації із медикаментозною корекцією при хірургічному лікуванні хворих на ГП III ступеня має переваги над традиційним лікуванням.

Висновки. У результаті проведеного дослідження вдосконалено технологічну ланку модифікованої операції Цешинського-Відмана-Неймана для лікування хворих на ГП хронічного перебігу III ступеня шляхом проведення періостальних пенетрацій. Ультраструктурно до 12 місяця після оперативного втручання у пародонті пацієнтів першої та другої груп простежується позитивна динаміка, однак більш якісні морфологічні перетворення відбуваються у пародонті пацієнтів, яким проведена періостальна пенетрація в комплексі з медикаментозною корекцією.

Ключові слова: генералізований пародонтит; удосконалена клаптева операція; ультрамікроскопічне дослідження.

(С). А. Огиенко, В. П. Пюрык, О. Г. Попадинец

Ивано-Франковский национальный медицинский университет

\section{Ультраструктурное состояние пародонта при усовершенствовании лоскутной операции в лечении больных генерализованным пародонтитом}

Резюме. Среди всех хирургических стоматологических заболеваний болезни пародонта занимают одно из ведущих мест, учитывая распространенность этой патологии среди населения и ее негативные последствия (потеря зубов и нарушение функций зубочелюстной системы). Тяжесть ГП, частые рецидивы и осложнения приводят к снижению качества жизни пациентов, значительных социально-экономических убытков, нарушение функции жевания и речи.

Цель исследования - повышение эффективности хирургического лечения больных ГП III степени тяжести путем усовершенствования отдельных технологических звеньев операций Цешинского-Видмана-Неймана.

Материалы и методы. Мы прооперировали 46 больных хроническим генерализованным пародонтитом (ГП) III степени, которых разделили на две группы: первая группа (20 человек) - проводили тра- 
диционную модифицированную операцию Цешинского-Видмана-Неймана; больным второй группы (26 человек) - модифицированную операцию Цешинского-Видмана-Неймана, усовершенствованную методикой пенетраций периоста с медикаментозной коррекцией (с использованием ротовых ванночек с мирамистином и аппликаций метилурациловой мази с мирамистином на ткани пародонта и послеоперационные швы с применением в послеоперационном периоде препарата «Глутаргин» (сначала в инъекциях № 5 внутривенно по 5 мл (2 г) в 200 мл 0,9 \% раствора натрия хлорида 2 раза в сутки, а затем в таблетках - 4 таблетки по 0,75 мг 3 раза в день на протяжении месяца).

Результаты исследований и их обсуждение. После проведенного лечения установлено, что средний показатель пробы Шиллера-Писарева был выше у больных первой группы $(2,5 \pm 0,05) \%$ по сравнению с соответствующим показателем второй $(0,95 \pm 0,04)$ \%. После лечения средний показатель индекса кровоточивости составил в первой группе $(0,77 \pm 0,04)$ балла и во второй группе - $(0,32 \pm 0,04)$ балла. Ультраструктурное состояние пародонта подвергается позитивным трансформациям в более сжатые сроки у пациентов второй группы. Таким образом, применение периостальной пенетрации с медикаментозной коррекцией при хирургическом лечении больных ГП III степени имеет преимущества перед традиционным лечением.

Выводы. В результате проведенного исследования усовершенствовано технологическую цепочку модифицированной операции Цешинского-Видмана-Неймана для лечения больных ГП хронического течения III степени путем проведения периостальных пенетраций. Ультраструктурно до 12 месяца после оперативного вмешательства в пародонте пациентов первой и второй групп прослеживается положительная динамика, однако более качественные морфологические преобразования происходят в пародонте пациентов, которым проведена периостальная пенетрация в комплексе с медикаментозной коррекцией.

ключевые слова: генерализированный пародонтит; усовершенствованная лоскутная операция; ультрамикроскопическое исследование.

\section{CS. A. Ohiienko, V. P. Piuryk, O. H. Popadynets}

Ivano-Frankivsk National Medical University

\section{Ultrastructural condition of periodontal disease in the improvement of flap operation in the treatment of patients with generalized periodontitis}

Summary. Among all surgical dental diseases periodontal disease occupies one of the leading places, taking into account the prevalence of this pathology among the population and its negative consequences (loss of teeth and impaired functions of the tooth-jaw system). The severity of GP, frequent relapses and complications leads to a decrease in the quality of life of patients, significant socio-economic losses, impaired chewing and speech. The aim of the study - to increase the effectiveness of surgical treatment of patients with GP III degree of severity by improving certain technological steps in the operations of Tseshynskyi-Widman-Neimann.

Materials and Methods. We operated 46 patients with chronic generalized paradontitis (GP) of the III degree, divided into two groups: group I (20 people), which was the traditional modified operation of Tseshynskyi-VidmanNeimann; Patients of the group II (26 persons) - modified operation of Teshynskyi-Vidman-Neimann, improved by the method of periost penetration with medical correction (using oral trays with miramistin and applications of methyluracil ointment with miramistin on periodontal tissues and postoperative sutures with application in the postoperative periods of the preparation "Glutargin “(First in injections No. 5 intravenous $5 \mathrm{ml}$ (2 g) per $200 \mathrm{ml}$ of 0.9 $\%$ sodium chloride solution 2 times a day and then in tablets -4 tablets of $0.75 \mathrm{mg} 3$ times a day for a month).

Results and Discussion. After the treatment, it was found that the average rate of the Schiller-Pysariev sample was higher in patients of group I $(2.5 \pm 0.05 \%)$ compared with the corresponding index of group II $(0.95 \pm$ $0.04 \%)$. After treatment, the average index of bleeding index was $(0.77 \pm 0.04)$ points in the group I and $(0.32$ \pm 0.04 ) points in the group II. The ultrastructural state of periodontal undergoes positive transformations in shorter terms in patients of the group II. Thus, the use of peristaltic penetration with medical correction in the surgical treatment of patients with a GP of the III degree has advantages over traditional treatment.

Conclusions. As a result of the research, the technological chain of the modified Tseshynskyi-Vidman-Neimann operation was improved for the treatment of GP patients with a chronic course of the third degree through periosteal penetration. Ultrastructurally up to the twelfth month after operative intervention in the periodontitis of patients of the first and second groups, a positive dynamics is observed; however, better morphological transformations occur in the periodontitis of patients who underwent periosteal penetration in combination with drug correction.

Key words: generalized paradontitis; advanced fracture surgery; X-ray and ultrasound research. 
Вступ. Серед усіх хірургічних стоматологічних захворювань хвороби пародонта займають одне 3 провідних місць, враховуючи поширеність цієї патології серед населення та ії негативні наслідки (втрата зубів і порушення функцій зубощелепної системи). Тяжкість ГП, часті рецидиви й ускладнення призводять до зниження якості життя пацієнтів, значних соціально-економічних збитків, порушення функції жування та мовлення. На думку вчених, досягнути успіху при лікуванні ГП без використання хірургічних методик неможливо [10-12]. Стандартом хірургічного лікування ГП III ступеня науковці вважають клаптеві операції на пародонті, але при їх виконанні недостатньої уваги надають періосту [1-3]. Періост - одна зі складових живлення кісткової тканини, тому при недостатній трофіці періосту відбувається розвиток ГП [6]. Це вимагає подальшої розробки нових схем лікування. У хірургії пародонта найбільше публікацій стосується післяопераційного періоду, профілактики ускладнень, шинування коренів рухомих зубів, направленої тканинної регенерації, корекції присінка рота. Аналізуючи сучасні наукові розробки, ми встановили, що функцію періосту при лікуванні ГП вивчено недостатньо [3-10].

Метою дослідження було підвищення ефективності хірургічного лікування хворих на ГП III ступеня тяжкості шляхом удосконалення окремих технологічних ланок операцій Цешинського-Відмана-Неймана.

Матеріали і методи. Прооперовано 46 хворих на ГП хронічного перебігу III ступеня, яких поділили на дві групи: перша (20 осіб) - операція Цешинського-Відмана-Неймана. Друга група (26 осіб), модифікована операція Цешинського-Відмана-Неймана, удосконалена методикою пенетрацій періосту з медикаментозною корекцією, яку ми розробили [10].

Авторське вдосконалення технологічної ланки операції Цешинського-Відмана-Неймана полягало у наступному: після відшарування слизово-окісного клаптя за допомогою кулястого бора проводили множинні пенетрації періосту з відстанню між ними 2-3 м і глибиною 1-1,5 мм, що проілюстровано на рисунку 1, 3 подальшим використанням ротових ванночок 3 мірамістином та аплікацій метилурацилової мазі з мірамістином на тканини пародонта та післяопераційні шви із застосуванням у післяопераційному періоді препарату «Глутаргін» (спершу в ін’єкціях № 5 внутрішньовенно по 5 мл (2 г) на 200 мл 0,9 \% розчину натрію хлориду 2 рази на добу, а потім у таблетках - 4 таблетки по 0,75 мг 3 рази на день протягом місяця) [6-8].
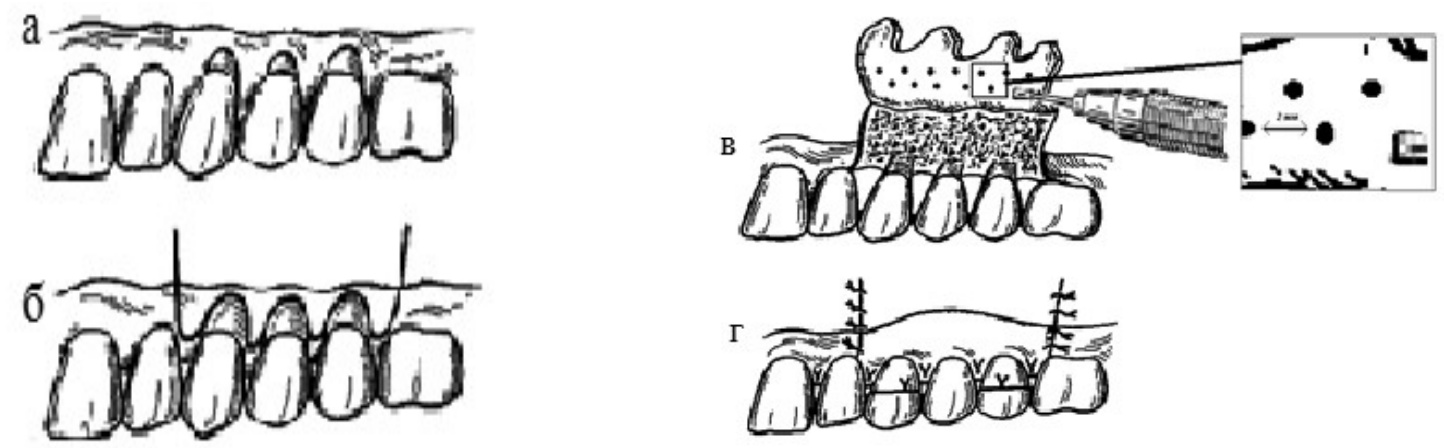

Puc. 1. Етапи удосконалення операції Цешинського-Відмана-Неймана: а - оголення шийок зубів - стан до операції, б - схема формування слизово-окісного клаптя, в - схема виконання пенетрації періосту, г - слизово-окісний клапоть укладено на місце і вшито вузлуватими швами.

У всіх хворих було отримано індивідуальну згоду на хірургічне лікування і проведення забору шматочків тканин пародонта в динаміці спостереження. Проводили клінічні, електронно-мікроскопічне дослідження. Індексну оцінку стану пародонта, застосовуючи пробу Шиллера-Писарєва та індекс кровоточивості, а також електронно-мікроскопічне дослідження, проводили до та через 1; 6 і 12 місяців після оперативного втручання [2, 12]. Для ви- значення вірогідності отриманих результатів проведено статистичну обробку цифрового матеріалу за допомогою StatSolf, Inc (2011 р.) та STATISTICA i Microsoft Excel (2010 p.).

Результати досліджень та їх обговорення. У пацієнтів першої та другої груп до початку лікування показник індексу Шиллера-Писарєва становив у середньому $(5,35 \pm 0,68)$ бала. Після лікування у хворих першої групи через 1 місяць спостерігали поліпшення гігієнічного 


\section{Хірургічна стоматологія}

стану ротової порожнини до $1,86 \pm 0,02$, а другої групи - до $(0,83 \pm 0,03)$ бала. Через 6 місяців у

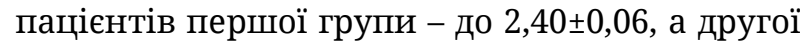
групи - до $(0,92 \pm 0,08)$ бала. Через 12 місяців у хворих першої групи - 3,29 $\pm 0,07$, а в пацієнтів другої групи - 1,1+0,02, що вказує на зменшення вираження та поширення запального процесу в пародонті у хворих другої групи (рис. 2).

Індекс кровоточивості сосочків за Мюхлеманном визначали у першій та другій групах шляхом зондування за допомогою гудзикового зонда в ділянці 16; 12; 24; 44; 32; 36, який до лікування в них складав $(2,80 \pm 0,08)$ бала. Через місяць після лікування у хворих першої групи - $(0,65 \pm 0,02)$ бала, а у хворих другої групи $(0,20 \pm 0,03)$ бала. Через 6 місяців після лікування у пацієнтів першої групи він складав $(0,79 \pm 0,03)$ бала, а у другої - $(0,35 \pm 0,05)$ бала. Через 12 міся-

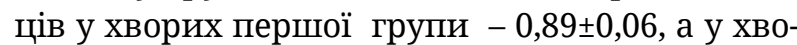
рих другої групи - 0,41ะ0,05 (рис. 3).

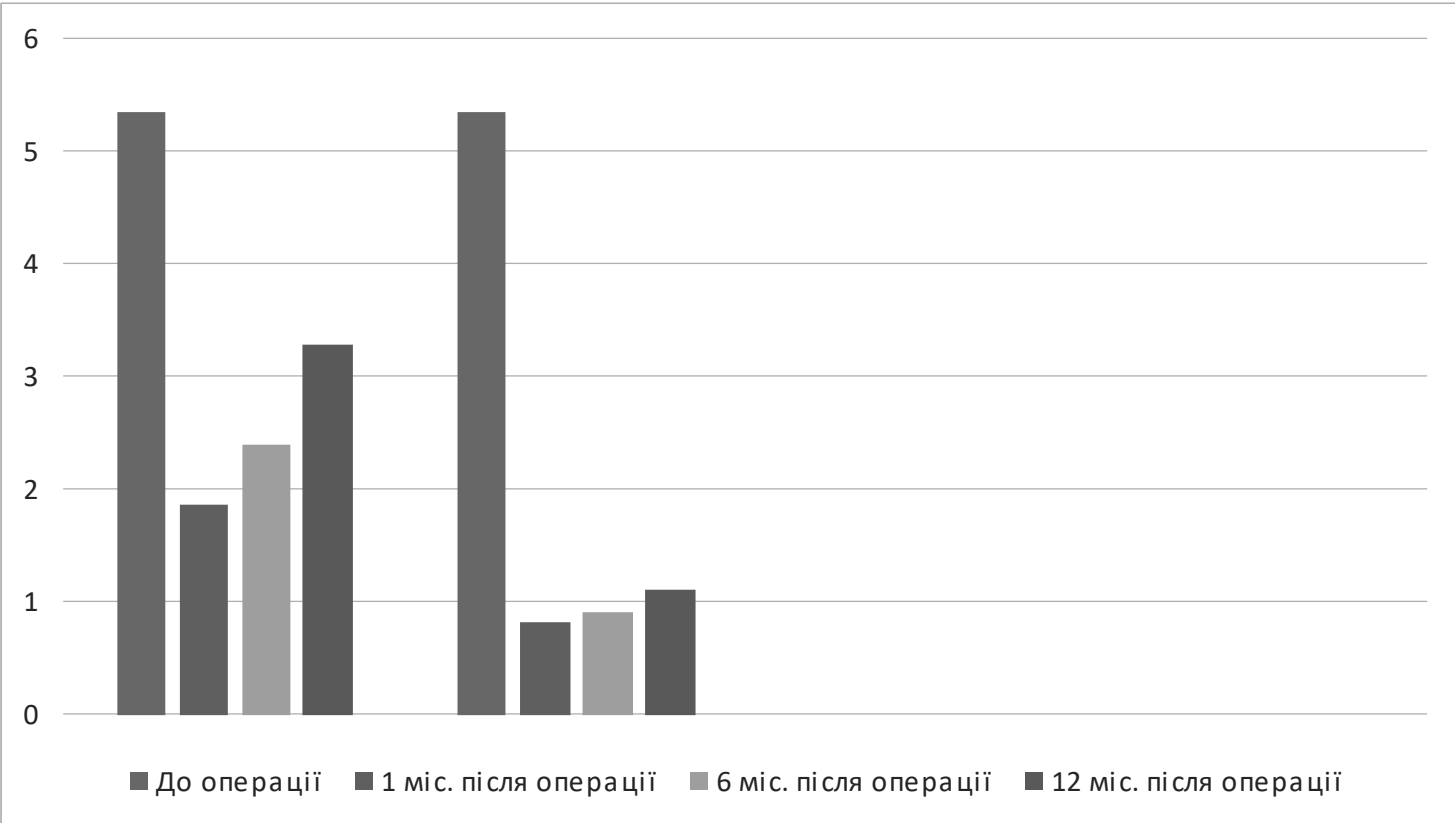

Puc. 2. Динаміка проби Шиллера-Писарєва у групах дослідження залежно від терміну спостереження.

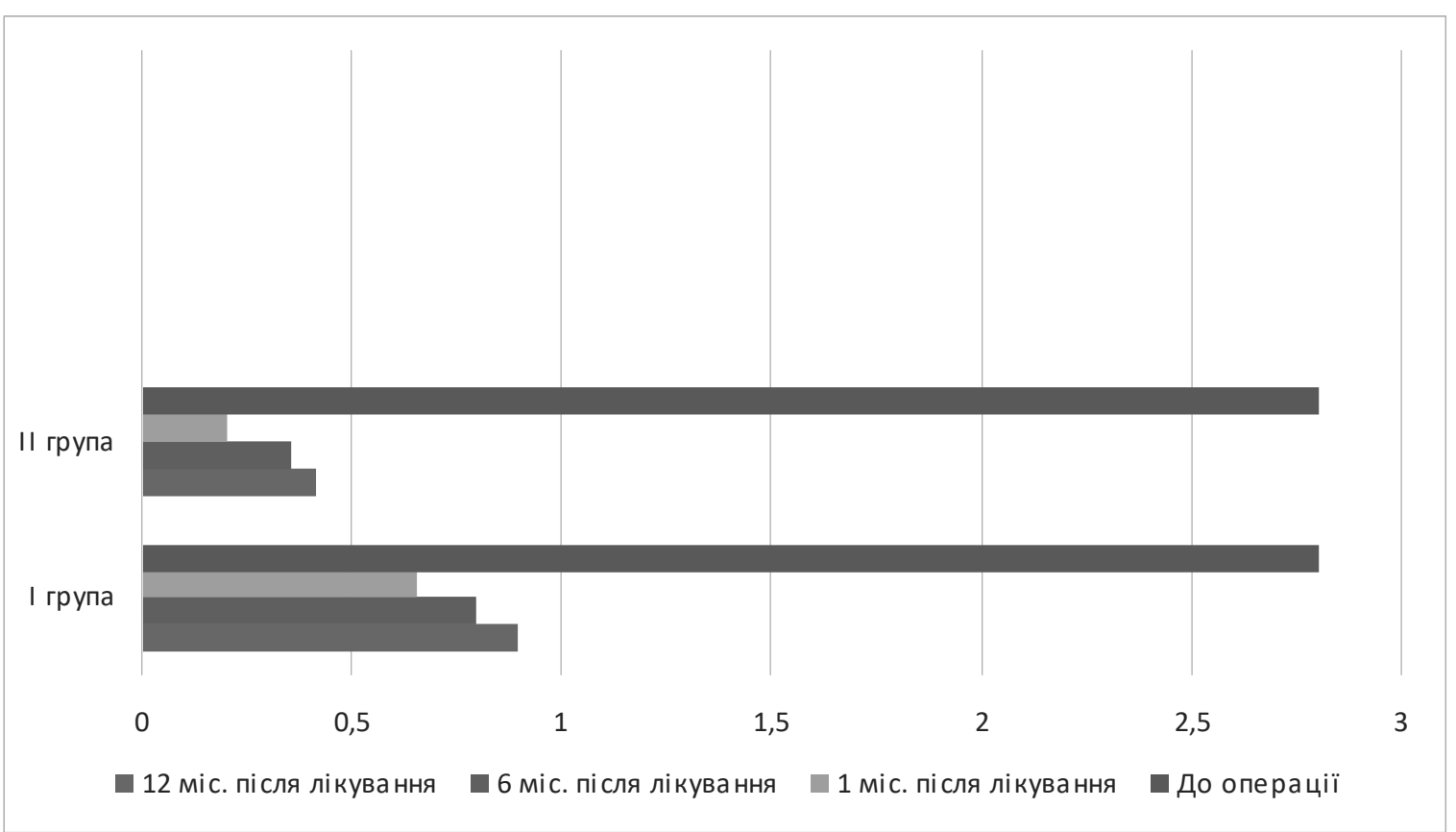

Puc. 3. Динаміка індексу кровоточивості сосочків за Мюхлеманном у групах дослідження залежно від терміну спостереження. 
При електронно-мікроскопічному дослідженні пародонта у пацієнтів із генералізованим парадонтитом до лікування спостерігаються зміни в стінці гемосудин та виражений паравазальний набряк. Просвіт артеріол деформований, у нього пролабують ядра ендотеліоцитів та випини їх люмінальної плазмолеми. Базальна мембрана оптично просвітлена, розщеплена та звивиста. Гладкі міоцити знаходяться в оточенні набряклих сполучнотканинних елементів судинної стінки, адвентиційна оболонка якої чітко не диференціюється і губиться в навколишній електронно-прозо- рій основній речовині з набряклими деструктурованими колагеновими волокнами. В усіх полях зору домінує набряк сполучнотканинних складових пародонта. Фібробласти мають численні витягнуті вирости, в цитоплазмі яких є поодинокі секреторні гранули з вмістом середньої електронної щільності. Основна речовина оптично розріджена. Цитоплазма клітин епітелію зубоясенного з'єднання набрякла, органели простежуються нечітко, візуалізуються протофіламенти. $€$ локуси інвагінації ядерної оболонки. Міжклітинні простори розширені (рис. 4).

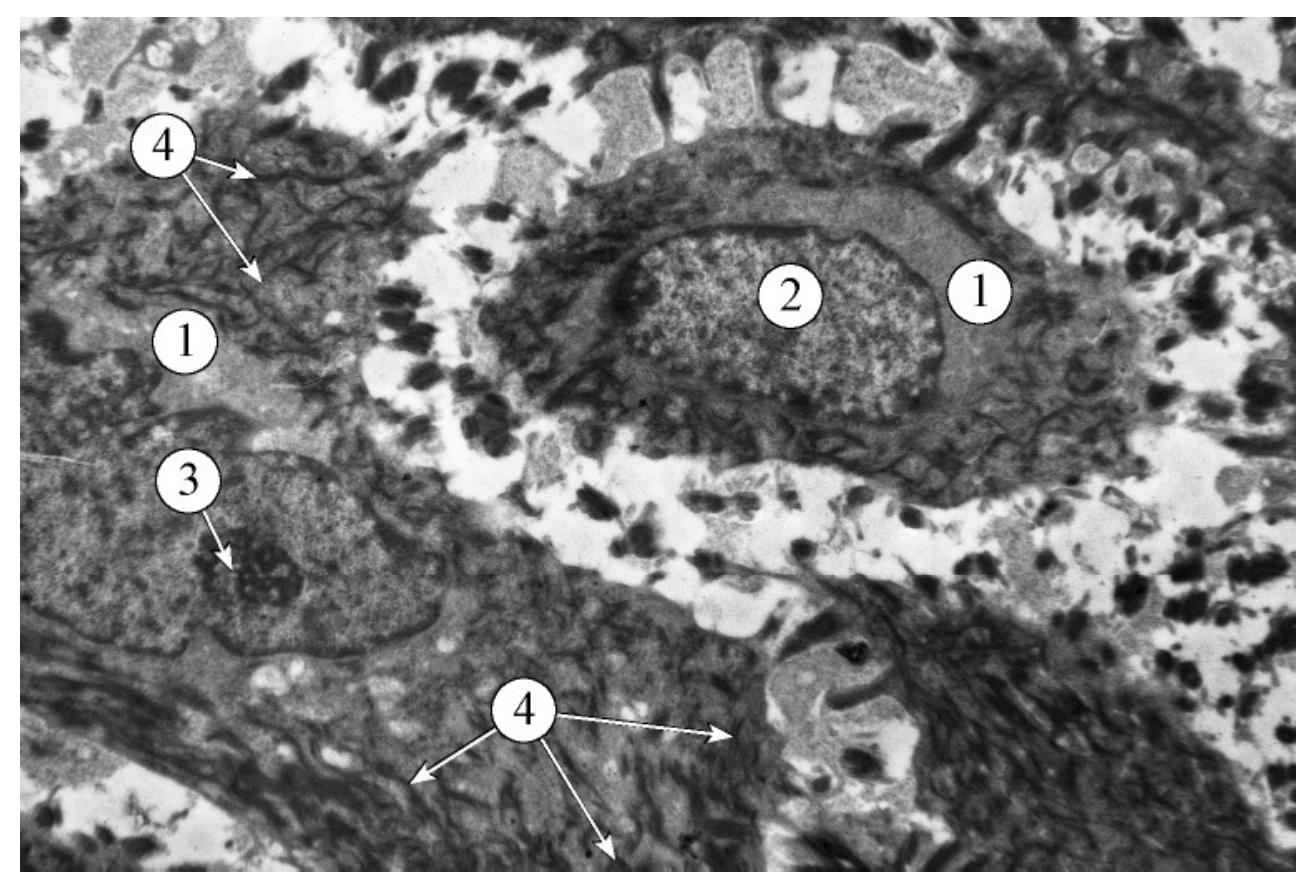

Puc. 4. Субмікроскопічна будова епітелію зубоясенного з’єднання при пародонтиті: 1 - цитоплазма епітеліоцитів, 2 - ядро епітеліоцита, 3 - ядерце, 4 - протофіламенти. Електронна мікрофотографія. 3б. 4800.

Через місяць після оперативного втручання у пацієнтів першої групи в пародонті спостерігаються набряково-дистрофічні процеси. Виражений сладж еритроцитів у просвіті гемосудин, ендотеліоцити деформовані, знаходяться на нечітко контурованій базальній мембрані (рис. 5). Сполучнотканинні елементи пародонта на даному етапі дослідження набряклі та дезорганізовані. Основна речовина оптично світла. Колагенові волокна візуалізуються тяжко, в більшості полів зору вони фрагментовані, їх пучки дезорганізовані. Ядерна оболонка фібробластів інвагінована, під нею зосереджений гетерохроматин. Навколо ядра знаходяться елементи ендоплазматичної сітки та апарату Гольджі. Цитоплазматичні відростки численні та множинно галузяться, занурюючись в основну речовину. В них знаходяться дрібні секреторні гранули.

Через місяць після оперативного втручання у пацієнтів другої групи в складових елементах пародонта виявляється едематоз. Колагенові волокна набряклі, дезорганізовані. Основна речовина мозаїчно просвітлена. Наявні локуси геморагічного просякання. Фібробласти в усіх полях зору мають численні відростки та активований синтетичний апарат. Ядра епітеліоцитів зубоясенного з'єднання овальної форми 3 рівномірно розподіленим хроматином. У цитоплазмі помітні мішечки і трубочки ендоплазматичної сітки та пухирці апарату Гольджі. Мітохондрії округлі, гребені дискомплектовані, матрикс гомогенний. Міжклітинні проміжки нерівномірно розширені (рис. 6). 


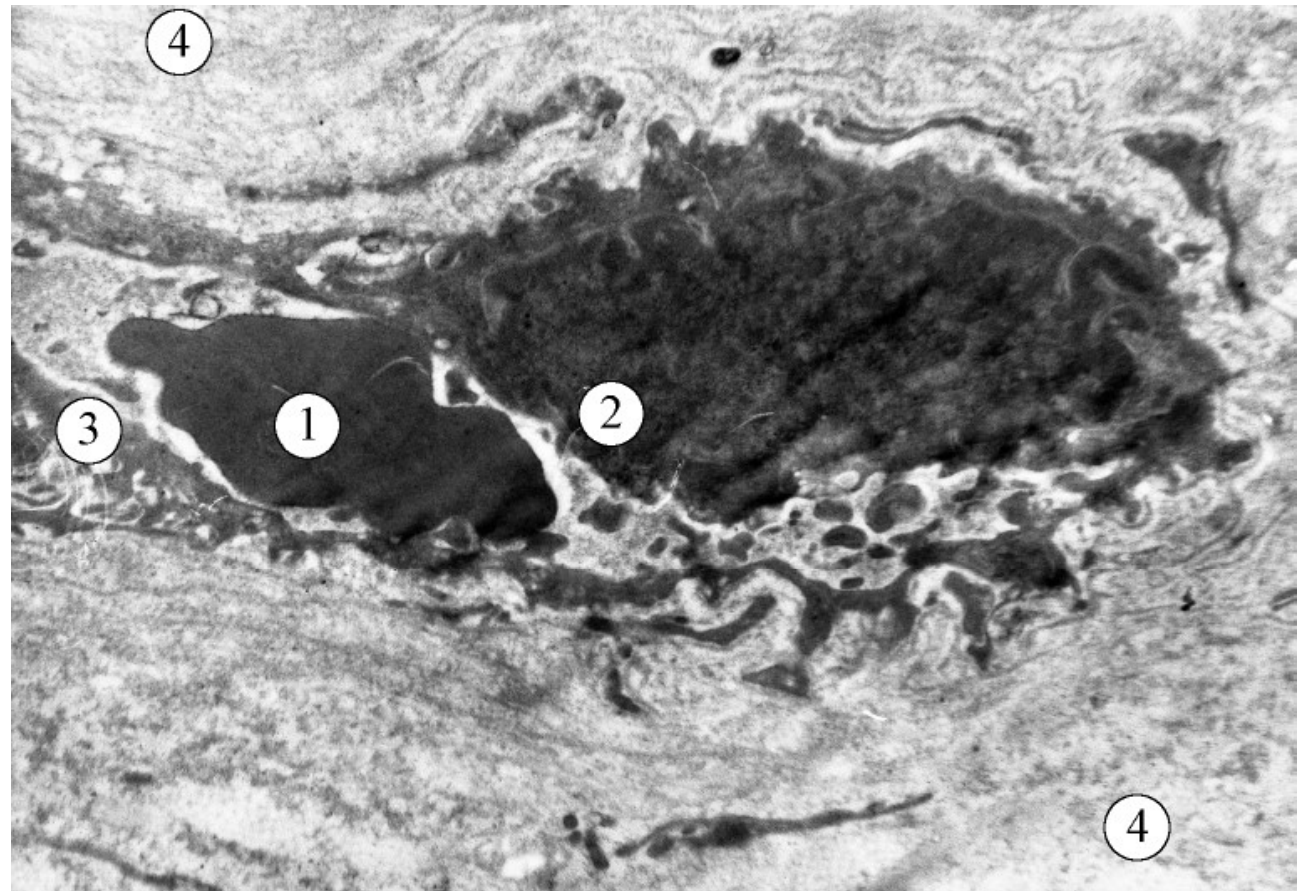

Puc. 5. Ультраструктура пародонта через місяць після оперативного втручання у пацієнтів першої групи: 1 - еритроцит у просвіті гемокапіляра, 2 - ядро фібробласта, 3 - відростки фібробласта, 4 - набрякла основна речовина власної пластинки. Електронна мікрофотографія. Зб. 6400.

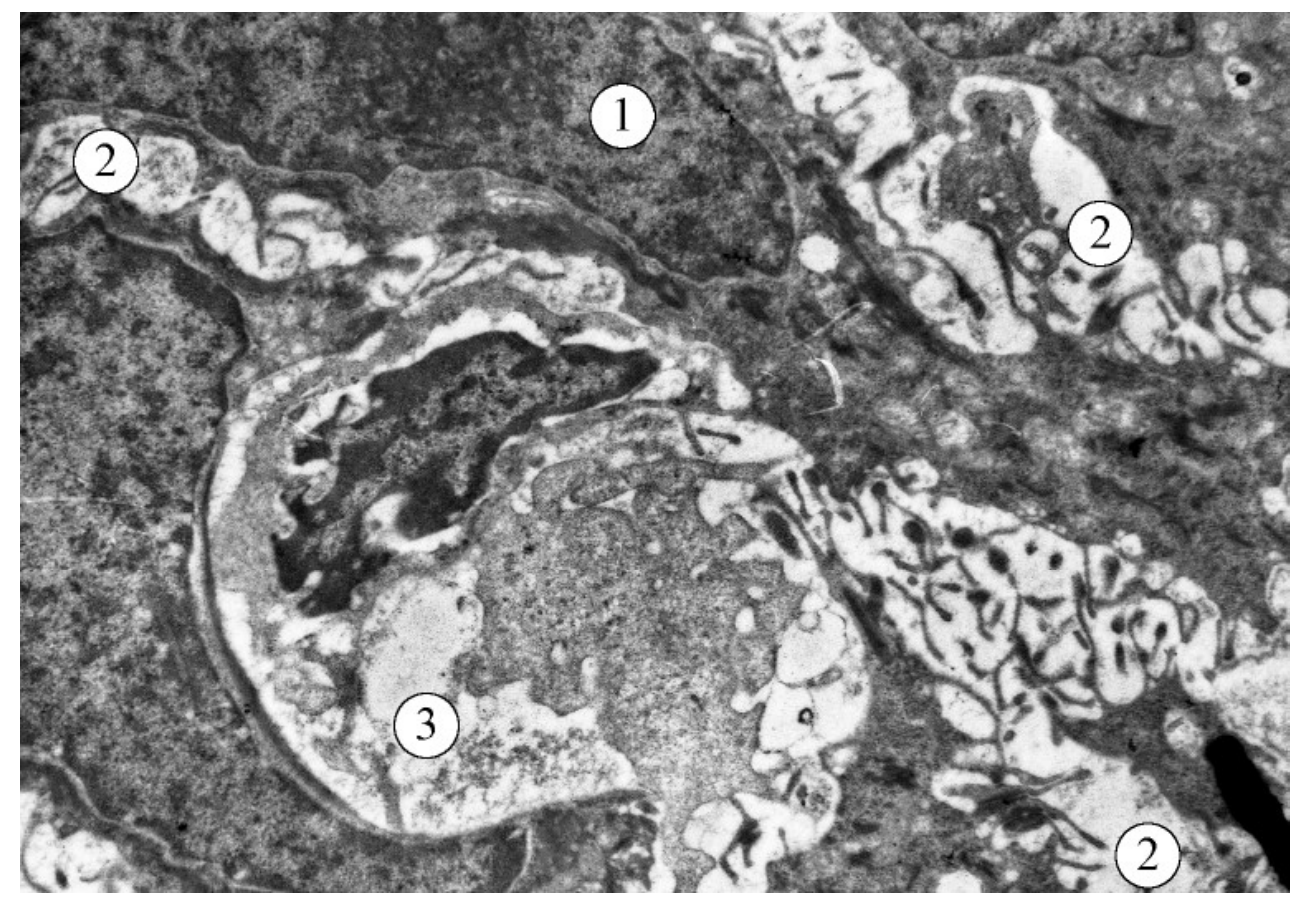

Puc. 6. Ультраструктура епітелію зубоясенного з'єднання у пацієнтів другої групи через місяць після оперативного втручання: 1 - ядро епітеліоцита, 2 - розширені міжклітинні простори, 3 - плазматичні просякання. Електронна мікрофотографія. Зб. 6400.

Через 6 місяців після оперативного втручання у пацієнтів першої групи в пародонті виявляються активовані фібробласти. В їх цитоплазмі візуалізуються розширені елементи синтетичного апарату, а у відростках - дрібні секреторні гранули. Навколо фібробластів організовується сполучнотканинний каркас, представлений колагеновими волокнами, більшість яких у деформованих пучках. У багатьох фібробластах виявляються ядерця, під ядерною оболонкою знаходяться гранули гетерохроматину. Біля ядра зосереджені численні мітохондрії (рис. 7). 


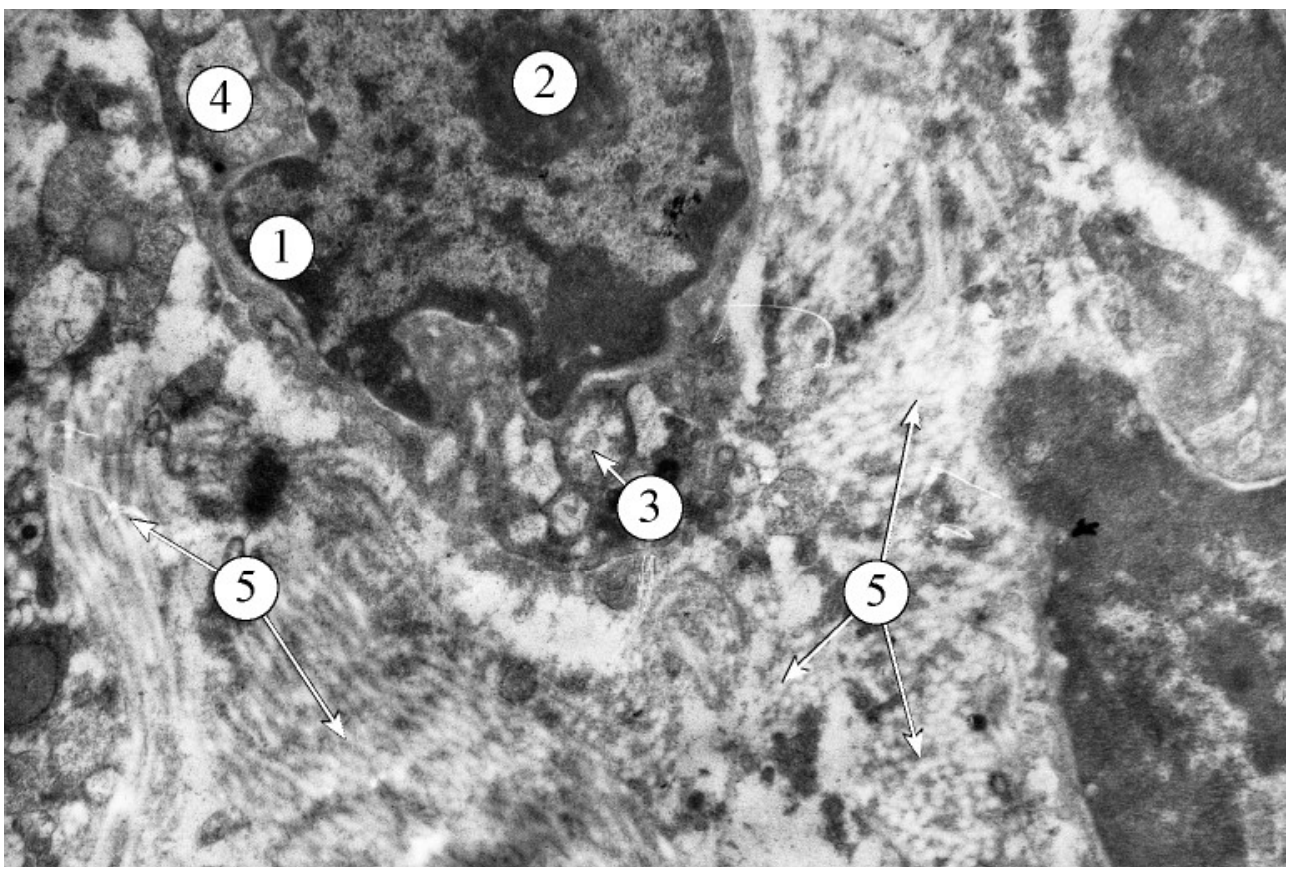

Puc. 7. Ультраструктура сполучнотканинних складових пародонта у пацієнтів першої групи через 6 місяців після оперативного втручання: 1 - ядро фібробласта, 2 - ядерце, 3 - мітохондрія, 4 - розширені цистерни ендоплазматичної сітки, 5 - пучки колагенових волокон. Електронна мікрофотографія. 3б. 6400.

Ядра епітеліоцитів зубоясенного з’єднання витягнутої овальної форми. В їх цитоплазмі простежуються невеликі мішечки і цистерни ендоплазматичної сітки та пухирці апарату Гольджі, поодинокі мітохондрії. Міжклітинні проміжки нерівномірно розширені та інфільтровані лімфоцитами (рис. 8).

Через 6 місяців після оперативного втручання у пацієнтів другої групи в епітелії зубо-ясен- ного з'єднання також виявляється лімфоцитарна інфільтрація, однак візуалізуються менш розширені міжклітинні проміжки (рис. 9). Цитоплазма епітеліоцитів середньої електронної щільності, добре помітні органели. Ядерна оболонка утворює невеликі випини, що чергуються із увігнутостями. У сполучнотканинному каркасі пародонта простежуються активні синтетично-організаційні процеси.

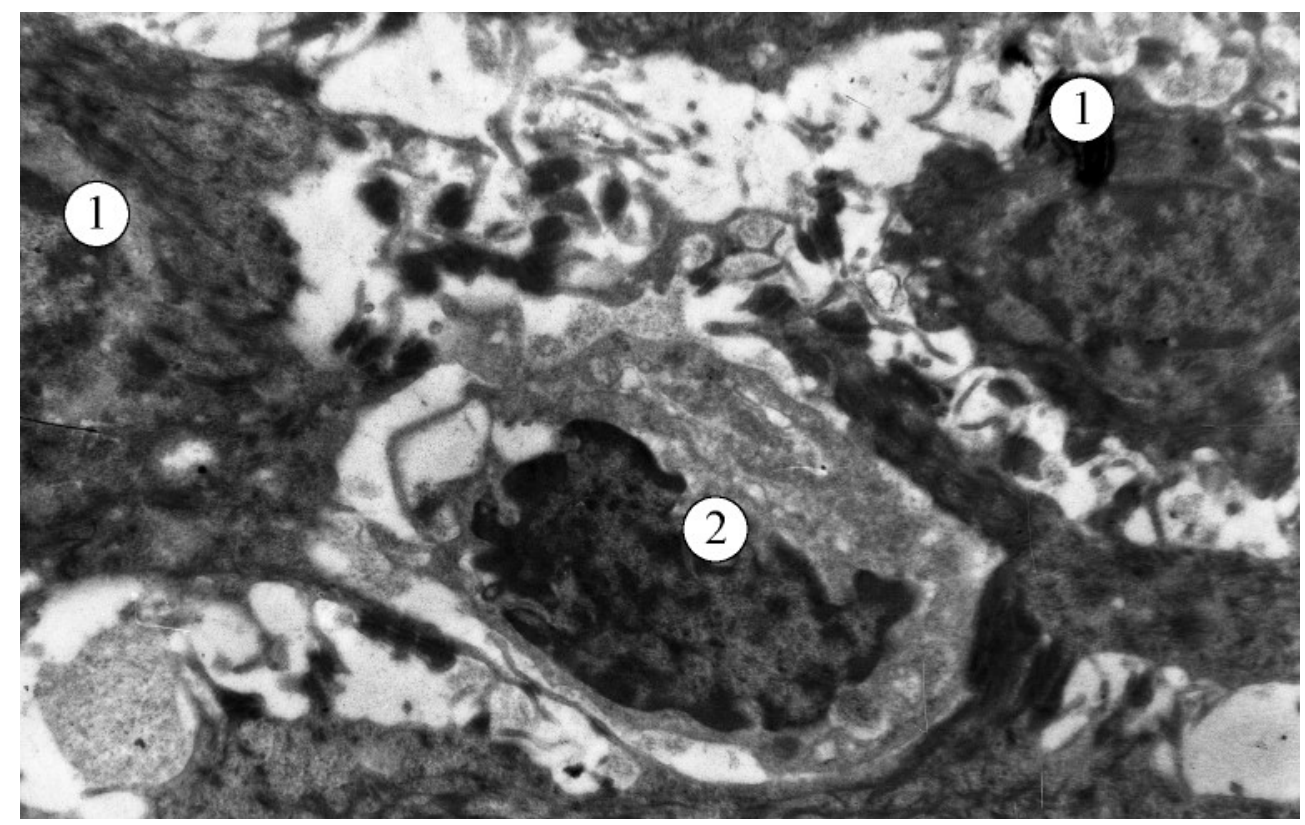

Puc. 8. Ультраструктура епітелію зубоясенного з’єднання у пацієнтів першої групи через 6 місяців після оперативного втручання: 1 - епітеліоцит, 2 - лімфоцит. Електронна мікрофотографія. 3б. 6400. 


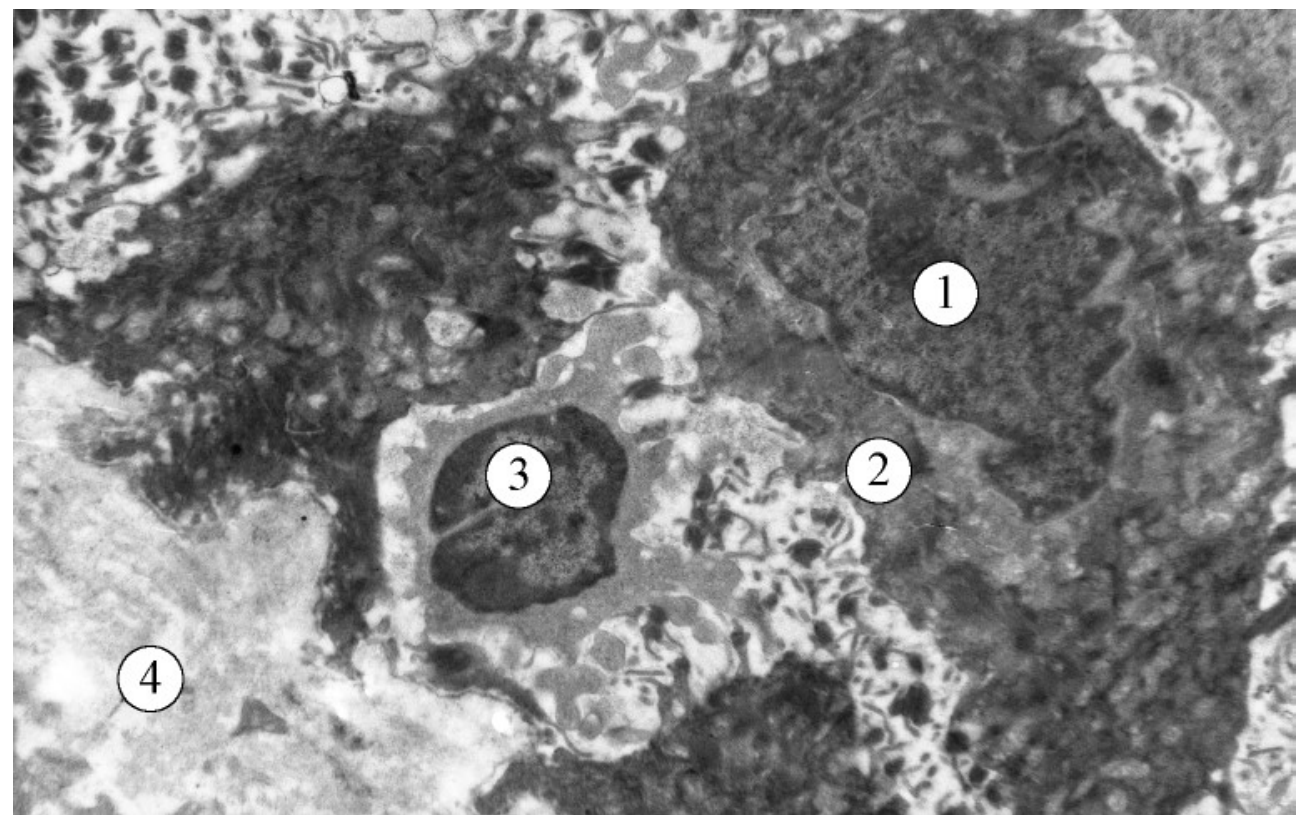

Puc. 9. Ультраструктура епітелію зубоясенного з’єднання у пацієнтів другої групи через 6 місяців після оперативного втручання: 1 - ядро епітеліоцита, 2 - цитоплазма епітеліоцита зубоясенного з'єднання, 3 лімфоцит, 4 - власна пластинка слизової оболонки. Електронна мікрофотографія. Зб. 4800.

Колагенові волокна впорядковуються у пучки, які добре помітні в усіх полях зору. В основній речовині виявляються також тонкі волокна різної електронної щільності. Фібробласти мають добре виражені цистерни і трубочки ендоплазматичної сітки. Виявляються проксимальні та дистальні трубчасто-мішкуваті сітки. Мітохондрії округлі, з добре вираженими гребенями та дисперсним матриксом. У численних широких відростках цитоплазми фібробластів також виявляються елементи синтетичного апарату та секреторні гранули різної електронної щільності. Можна простежувати їх присутність і за межами фібробластів у безпосередній близькості до їх плазмолеми.

Через 12 місяців після оперативного втручання у пацієнтів першої групи при дослідженні пародонта виявляються стоншені та гомогенізовані пучки колагенових волокон. В окремих полях зору можна простежувати їх повздовжню періодичність, коли чергуються темні та світлі смуги (рис. 10).

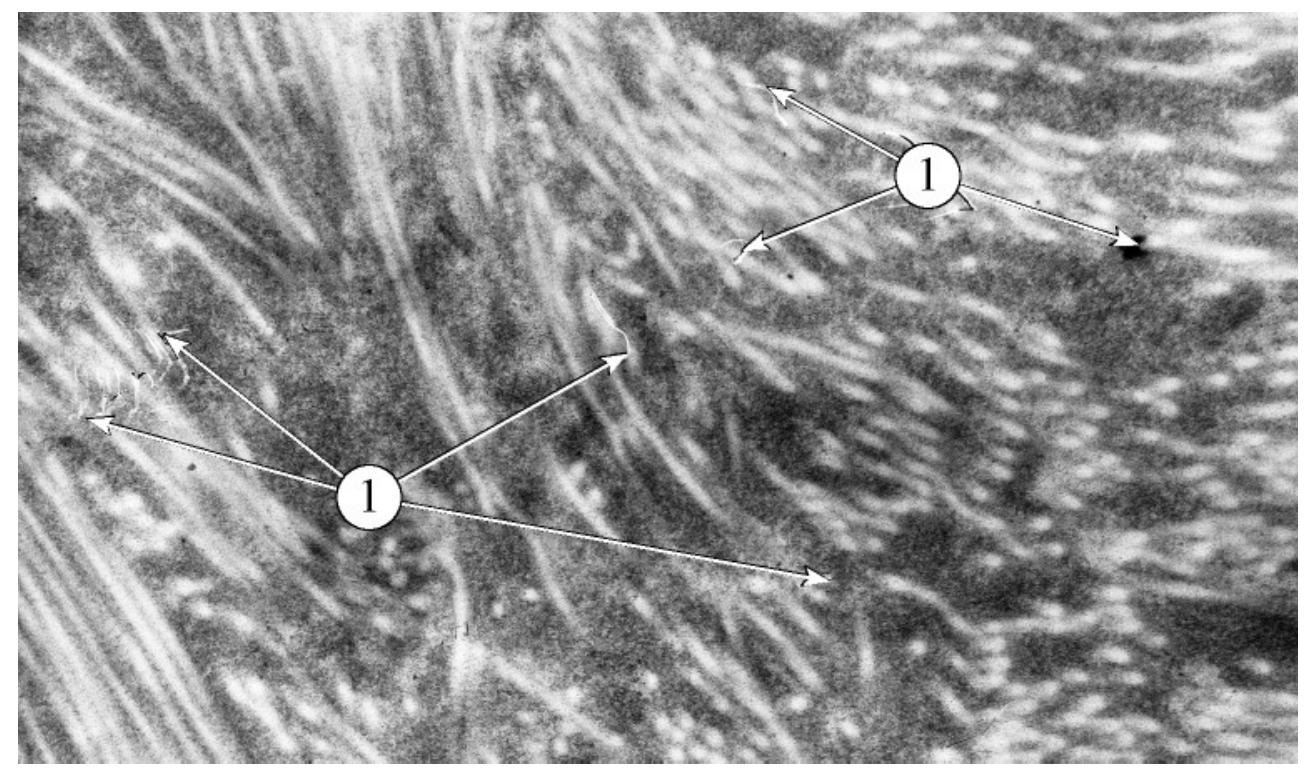

Puc. 10. Ультраструктурна організація сполучнотканинних волокон пародонта у пацієнтів першої групи через 12 місяців після оперативного втручання: 1 - різнонаправлені переплетені пучки колагенових волокон. Електронна мікрофотографія. Зб. 9600. 
Клітини епітелію зубоясенного з'єднання мають добре контуровані ядра з помітними ядерцями та рівномірно розподіленим хроматином. У цитоплазмі візуалізуються органели, які представлені пухирцями апарату Гольджі та мішечками і цистернами ендоплазматичної сітки. У мітохондріях не завжди візуалізуються чітко гребені, матрикс диспергований. Міжклітинні простори розширені (рис. 11).
Через 12 місяців після оперативного втручання у пацієнтів другої групи ультраструктура пародонта свідчить про зниження активності патологічних процесів і стабілізацію його мікроморфології. Стінка гемокапілярів представлена ендотелієм на чітко контурованій базальній мембрані. Паравазально знаходяться колагенові волокна, пучки яких направлені повздовжньо, косо та перпендикулярно. Спо-

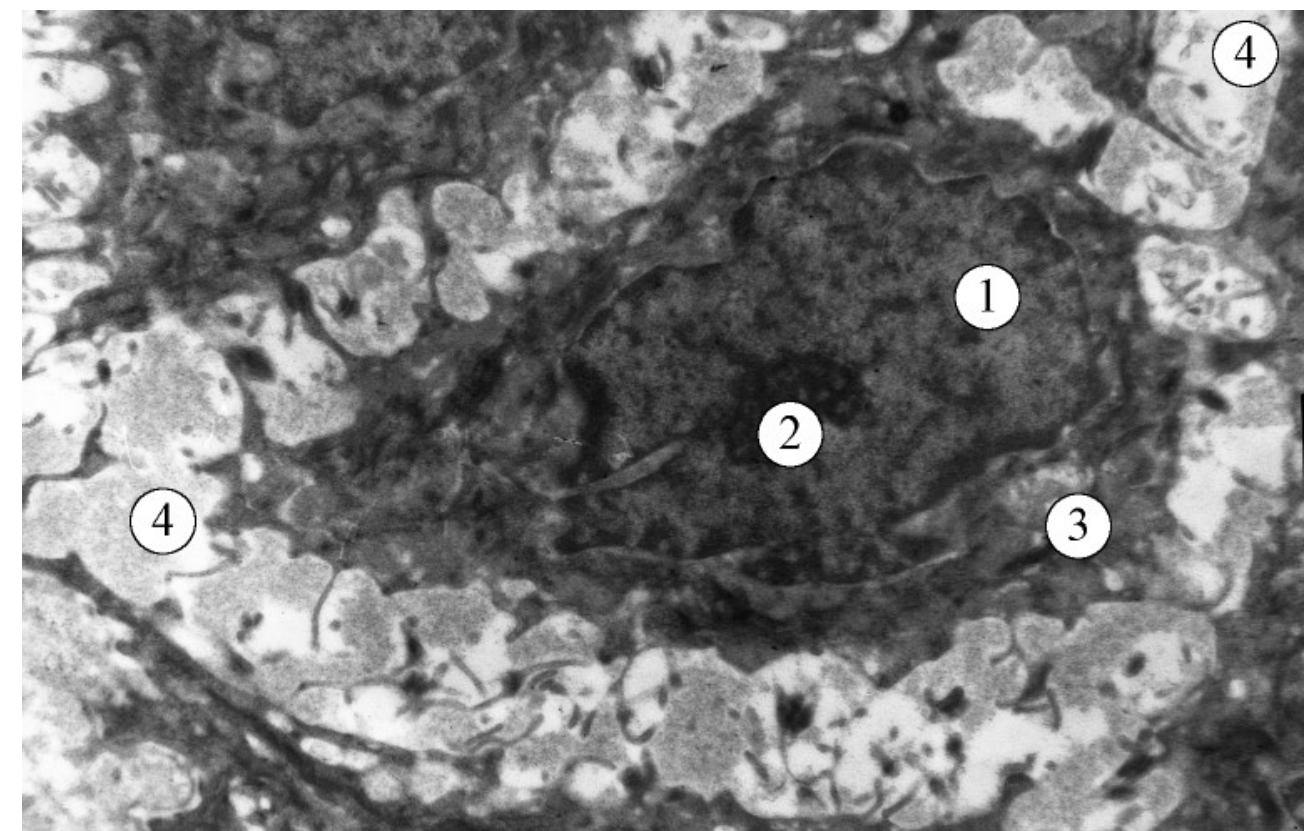

Puc. 11. Ультраструктура епітелію зубоясенного з'єднання у пацієнтів першої групи через 12 місяців після оперативного втручання: 1 - ядро епітеліоцита, 2 - ядерце епітеліоцита, 3 - цитоплазма епітеліоцита, 4 набряклі міжклітинні простори. Електронна мікрофотографія. Зб. 6400.

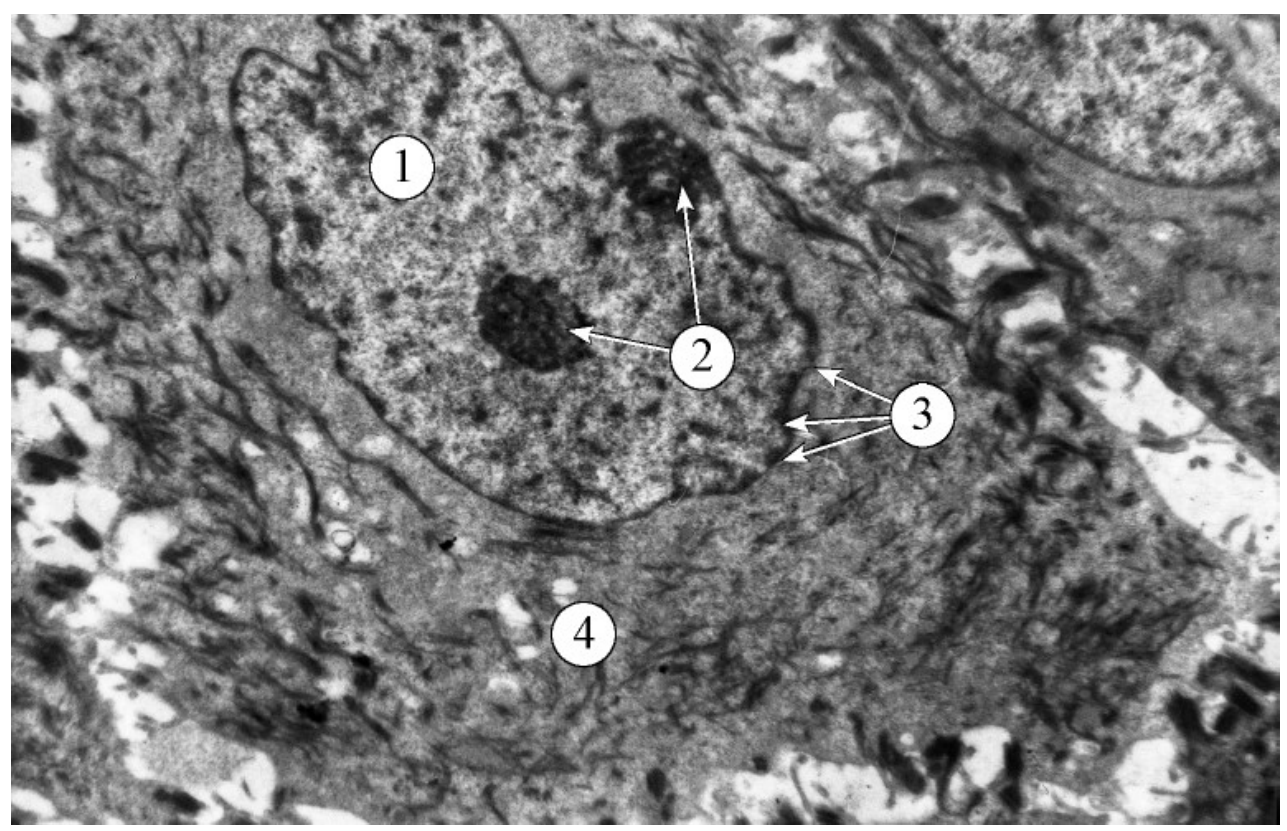

Puc. 12. Ультраструктура епітелію зубоясенного з'єднання у пацієнтів другої групи через 12 місяців після оперативного втручання: 1 - ядро епітеліоцита, 2 - ядерце, 3 - ядерна оболонка, 4 - цитоплазма епітеліоцита. Електронна мікрофотографія. Зб. 4800. 
лучнотканинний каркас пародонта на даному етапі дослідження має впорядковану організацію. Виявляються колагенові волокна високої та низької електронної щільності, в більшості яких простежується поперечна посмугованість. Виявляються також і тонкі незрілі волокна в оточенні диспергованої основної речовини.

У клітинах епітелію зубоясенного з'єднання виявляються овальні ядра з ядерцями та рівномірно розподіленим хроматином. У цитоплазмі присутні невеликі трубочки ендоплазматичної сітки, пухирці апарату Гольджі, мітохондрії. Міжклітинні простори незначно розширені (рис. 12).

Таким чином, із вищенаведених даних можна зробити висновок, що хірургічне лікування хворих на ГП III ступеня із застосуванням періостальної пенетрації в комплексі 3 медикаментозною корекцією має переваги над традиційним, а використання розробленої методики періостальних пенетрацій є доцільним.

\section{Список літератури}

1. Агзамова Л. Р. Оптимизация хирургического лечения хронического генерализованного пародонтита / Л. Р. Агзамова // Медицинский вестник Башкортостана. - 2010. - № 4. - С. 97-102.

2. Заболотний Т. Д. Ультразвуковая эхоостеометрия (УэОМ) в диагностике и лечении заболеваний пародонта / Т. Д. Заболотний // Методика диагностики, лечения и профилактики основных стоматологических заболеваний. - 1990. - С. 107-108.

3. Махлинець Н. П. Комплексне лікування хворих на генералізований пародонтит із мілким присінком рота / Н. П. Махлинець // Галицький лікарський вісник. - 2015. - Т. 22, № 2. - С. 63-65.

4. Мельничук А. С. Динаміка деяких біохімічних показників ротової рідини під впливом комплексного лікування хворих на генералізований пародонтит у різні терміни спостереження / А. С. Мельничук, Р. С. Кашівська, У. Р. Василишин // Стоматологія XXI століття. Естафета поколінь : наук.-практ. конф. 3 міжнар. уч. : тез. доп., 2-3 квітня 2013 р. - Одеса, 2013. - C.189-190.

5. Оцінка показників маркерів кісткового ремоделювання в комплексному лікуванні генералізованого пародонтиту / Г. Б. Проць, В. П. Пюрик, Ю. І. Солоджук // Галицький лікарський вісник. - 2016. T. 23, № 2. - С. 34-37.

6. Пат. № 93799 Україна, МПК А61В 17/24 (2006.01). Спосіб стимуляції репаративних процесів у пародонті / Пюрик В. П., Огієнко С. А., Пюрик Я. В.; заявники і патентовласники Пюрик В. П., Огієнко С. А., Пюрик Я. В. - № u 2014 05833; заявл. 29.09.2014; опубл. 10.10.2014, Бюл. № 19.
Висновки. 1. У результаті проведеного дослідження вдосконалено технологічну ланку модифікованої операції Цешинського-Відмана-Неймана для лікування хворих на ГП хронічного перебігу III ступеня шляхом проведення періостальних пенетрацій.

2. Ультраструктурно до 12 місяця після оперативного втручання у пародонті пацієнтів першої та другої груп простежується позитивна динаміка, однак більш якісні морфологічні перетворення відбуваються у пародонті пацієнтів, яким проведена періостальна пенетрація в комплексі з медикаментозною корекцією.

Перспективи подальших досліджень. Будуть вивчені віддалені результати запропонованого методу вдосконалення технологічної ланки операції Цешинського-Відмана-Неймана для лікування хворих на ГП хронічного перебігу III ступеня. Планується вивчити ультраструктурні зміни тромбоцитів після хірургічного втручання на тканинах пародонта.

7. Пат. № 105402 Україна, МПК А61В 17/24 (2006.01). Спосіб корекції остеогенезу при лікуванні хворих на тяжку форму генералізованого пародонтиту / Пюрик В. П., Огієнко С. А., Пюрик Я. В.; заявники і патентовласники Пюрик В. П., Огієнко С. А., Пюрик Я. В. - № а 2015 00601; заявЛ. 26.01.2015; опубл. 25.03.2016, Бюл. № 6.

8. Пат. № 111458 Україна, МПК (2016.01) А61В 17/24 (2006.01) А61К 31.00 А61P 1/02 (2006.01). Спосіб комплексного лікування хворих на генералізований пародонтит II-III ступеня / Пюрик В. П., Огієнко С. А., Пюрик Я. В.; заявники і патентовласники Пюрик В. П., Огієнко С. А., Пюрик Я. В. - № а 201508662 ; заявл. 07.09.2015; опубл. 25.04.2016, Бюл. № 8.

9. Підвищення ефективності мукогінгівоостеопластики в лікуванні хворих на тяжку форму генералізованого пародонтиту шляхом множинної пенетрації періосту / В. П. Пюрик, С. А. Огієнко, Я. В. Пюрик [та ін.] // Галицький лікарський вісник. - 2016. - Т. 23, № 2. - С. 37-40

10. Пюрик В. П. Трансплантація кісткового мозку при лікуванні пародонтиту і кісткових порушень щелеп : автореф. дис. на здобуття наук. ступеня д-ра мед. наук. - Івано-Франківський мед. ін-т. - К., 1993. -36 c.

11. López A. Assessment of morbidity after periodontal resective surgery / A. López, J. Nart, A. Santos // Periodontol. - 2011. - Vol. 82, № 11. - P. 1563-1569.

12. Muhlemann H. R. Gingival sulcus bleeding - a leading symptom in initial gingivitis / H. R. Muhlemann, S. Son // Helvetia Odontologia Acta. -1971. - Vol. 15. - P. 107-113. 


\section{References}

1. Agzamova, L.R. (2010). Optimizatsiya khirurgicheskogo lecheniya khronicheskogo generalizovannogo parodontita [Optimization of surgical treatment of chronic generalized periodontitis]. Meditsinskiy vestnik Bashkortostana - Medical Journal of Bashkortostan, (4), 97-102 [in Russian].

2. Zabolotnyy, T.D. (1990). Ultrazvukovaya ekhoosteometriya (UEOM) $\mathrm{v}$ diagnostike i lechenii zabolevaniy parodonta [Ultrasonic echoostometry (UEOM) in the diagnosis and treatment of periodontal diseases]. Metodika diagnostiki, lecheniya i profilaktiki osnovnykh stomatologicheskikh zabolevaniy - Methods of Diagnosis, Treatment and Prevention of Major Dental Diseases, 107-108 [in Russian].

3. Makhlynets, N.P. (2015). Kompleksne likuvannia khvorykh na heneralizovanyi parodontyt iz milkym prysinkom rota [Complex treatment of patients with generalized periodontitis with a small prick of the mouth]. Halytskyi likarskyi visnyk - Galician Medicinal Journal, (22), 2, 63-65 [in Ukrainian].

4. Melnychuk, A.S., Kashivska, R.S. \& Vasylyshyn, U.R. (2013). Dynamika deiakykh biokhimichnykh pokaznykiv rotovoi ridyny pid vplyvom kompleksnoho likuvannia khvorykh na heneralizovanyi parodontyt u rizni terminy sposterezhennia [Dynamics of some biochemical parameters of oral liquid under the influence of complex treatment of patients with generalized periodontitis in different terms of observation]. Stomatolohiia XXI stolittia. Estafeta pokolin: nauk.-prakt. konf. z mizhnar. uch.: tez. dop., 2-3 kvitnia - Dentistry of the XXI century. Relaunch of Generations: Sciences. Pract. Conf. from International Student: Theses of Reports, April 2-3, Odesa, 189-190 [in Ukrainian].

5. Prots, H.B., Piuryk, V.P. \& Solodzhuk, Yu.I. (2016). Otsinka pokaznykiv markeriv kistkovoho remodeliuvannia $\mathrm{v}$ kompleksnomu likuvanni heneralizovanoho parodontytu [Evaluation of indicators of markers of bone remodeling in the complex treatment of generalized periodontitis]. Halytskyi likarskyi visnykGalician Medicinal Journal, (23), 2, 34-37 [in Ukrainian].

6. Piuryk, V.P., Ohiienko, S.A. \& Piuryk, Ya.V. (2016). Sposib stymuliatsii reparatyvnykh protsesiv u parodonti [A method of stimulation of reparative processes in parodontium]. Pat. No 93799 Ukraina, MPK A61V 17/24
(2006.01). Zaiavnyky i patentovlasnyky Piuryk, V.P., Ohiienko, S.A., Piuryk, Ya.V. No u 2014 05833. Zayavl. 29.09.2014; opubl. 10.10.2014, Byul. No 19 [in Ukrainian]. 7. Piuryk, V.P., Ohiienko, S.A. \& Piuryk, Ya.V. (2016). Sposib korektsii osteohenezu pry likuvanni khvorykh na tyazhku formu heneralizovanoho parodontytu [Method of correction of osteogenesis in the treatment of patients with severe forms of generalized periodontitis]. Pat. No 105402 Ukraina, MPK A61V 17/24 (2006.01). Zaiavnyky i patentovlasnyky Piuryk, V.P., Ohiienko, S.A. \& Piuryk, Ya.V. No. a 2015 00601; zayavl. 26.01.2015; opubl. 25.03.2016, Biul. No. 6 [in Ukrainian].

8. Piuryk, V.P., Ohiienko, S.A. \& Piuryk, Ya.V. (2016). Sposib kompleksnoho likuvannia khvorykh na heneralizovanyi parodontyt II-III stupenia [A method of complex treatment of patients with generalized periodontitis of II-III degrees]. Pat. No. 111458 Ukraina, MPK (2016.01) A61V 17/24 (2006.01) A61K 31.00 A61R 1/02 (2006.01). Zayavnyky i patentovlasnyky Piuryk, V.P., Ohiienko, S.A., Piuryk, Ya.V. - No. a 2015 08662; zayavl. 07.09.2015; opubl. 25.04.2016, Byul. No. 8 [in Ukrainian]. 9. Piuryk, V.P., Ohiienko, S.A. \& Piuryk, Ya.V. (2016). Pidvyshchenniaefektyvnosti mukohinhivoosteoplastyky $\mathrm{v}$ likuvanni khvorykh na tiazhku formu heneralizovanoho parodontytu shliakhom mnozhynnoi penetratsii periostu [Improvement of the effectiveness of mucogingivo-osteoplasty in the treatment of patients with severe forms of generalized periodontitis by multiple penetration of periosteum]. Halytskyi likarskyi visnyk - Galician Medicinal Journal, (23), 2, 37-40 [in Ukrainian].

10. Piuryk, V.P. (1993). Transplantatsiia kistkovoho mozku pry likuvanni parodontytu i kistkovykh porushen shchelep [Bone marrow transplantation in the treatment of periodontitis and bone disorders of the jaws]. Doctor's thesis: Ivano-Frankivsk med. in-t. Kyiv [in Ukrainian].

11. López, A., Nart, J. \& Santos, A. (2011). Assessment of morbidity after periodontal resective surgery. Periodontol., (82), 11, 1563-1569.

12. Muhlemann, H.R. \& Son, S. (1971). Gingival sulcus bleeding - a leading symptom in initial gingivitis. Helvetia Odontologia Acta, (15), 107-113.

Отримано 05.09.17 